Scientific Research Paper, Volume 1, submitted 17, 2018

\title{
THE EFFECT OF DIGITAL MARKETING ON PERFORMANCE OF COMMERCIAL BANKS IN RWANDA (2013-2017)
}

\author{
Ms. Dianah MUTONI
}

Department of Marketing, College of Business and Economics at University of Rwanda-Kigali Tutorial Assistant: College of Business and Economics at University of Rwanda

\begin{abstract}
The main purpose of this study was to assess the effect of digital marketing on performance of commercial banks in Rwanda. The specific objectives were to identify the common digital marketing platforms used by the commercial banks in Rwanda; to determine the extent to which the application of digital marketing has improved customers convenience as channel of performance of commercial banks in Rwanda; and to assess how the application of digital marketing help in reducing marketing cost against traditional marketing in commercial banks in Rwanda. This study employed a descriptive cross sectional survey design where it was used to gather information on a population of 243 employees. The sample sizes were 46 employees from BPR and the 25 employees from Equity Bank. In addition, the data analysis was done with the help of SPSS to show the relationship between digital marketing and performance of BPR Atlas Mara and Equity Bank Rwanda. The findings revealed that common digital marketing platforms used by commercial banks in Rwanda were Google Ad, Blogger; E-mail, and Tweeter as confirmed by respondents selected from BPR Atlas Mara, Equity Bank Rwanda. The application of digital marketing at BPR Atlas Mara, and Equity Bank Rwanda improved the customers' convenience as channel of performance where Mobile banking, account management, Card Payments, and Money transfers were done through application of digital marketing at BPR Atlas Mara and Equity Bank-Rwanda. According to the findings there is significant effect of digital marketing on performance of commercial banks in Rwanda.
\end{abstract}

Index Terms: Digital marketing, Performance, Customers' convenience, and ommercial banks

\section{Introduction}

The world at the time is experiencing a new global economic order that characterized by information and communication technologies. A whole remarkable change is taking place in which the spread of knowledge is giving a rise to an era of knowledge and information. These dramatic turns are taking an extreme lead in challenging for small developing economies like Rwanda. Fortunately, knowledge, and technology offer such countries like Rwanda, with no big mines and a landlocked a platform on which to build a future and become part of the global digital economy (Mosawi, et al., 2016).

Rwandan banking sector is embracing electronic or digital marketing technology with its due advantages. Digital marketing in particular offers the traditional players in the financial services 
sector the opportunity to add a low-cost advertising channel to their numerous platforms. The banking sector plays a significant role in the growth of economies all over the world especially Rwanda.

Rwandan banks are trying to enforce the banking services but they are still faced with some challenges which need to be addressed in order to promote effective and efficient banking performance, these challenges are the development of an efficient monetary transfer system in Rwanda has been hampered by so many factors. Rwanda also faces the challenge of infrastructural deficiency such as erratic power supply and communication link in some areas, inadequate skilled managers and requisite tool on end users and client systems, high charge or cost for the e-employment terminals (ATMs) so the banking legislation should set out standard charges for e-employment services. The impact of digital marketing on the Rwandan commercial banks still remains unknown. It should also be noted that no substantial academic research has been done in Rwanda on the effect of digital marketing to the performance of commercial banks in Rwanda as gap.

\section{Statement of the Problem}

The rise of digital marketing has had profound effects on the advertising industry and it is shaping the marketing experience. Going forward, the effectiveness and low cost of digital marketing compelled many businesses to rethink the size and makeup of their advertising budgets. The problems of this study were to investigate on which common digital marketing platforms are used by the commercial banks in Rwanda; how does the applications of digital marketing has improved customers convenience as channel of performance of commercial banks in Rwanda, and how does digital marketing affect performance of commercial banks in Rwanda especially BPR Atlas Mara and Equity Bank.

\section{Objectives of the Study}

i. To identify the common digital marketing platforms used by the commercial banks in Rwanda,

ii. To determine the extent to which the application of digital marketing has improved customers convenience as channel of performance of commercial banks in Rwanda,

iii. To assess how the application of digital marketing help in reducing marketing cost against traditional marketing in commercial banks in Rwanda.

\section{IV.LITERATURE REVIEW}

Digital marketing became popular because of the e-commerce, in other words, online shops. The main reason why digital marketing is being used in businesses is the lower cost and reachability compared to traditional marketing. For example, to reach 2,000 customers by newspaper or direct mailing the budget is around 200-900 dollars but with digital marketing the cost of advertisement is around 50-75 dollars (Bhargava, 2015). 
Digital marketing platforms are intended to support an extensible set of requirements within a single neighbourhood or two. A digital marketing platform unveils key elements as standardized services via a programmatic application programming interface for building custom applications, extensions and integrations with other custom and commercial applications and data sources. Some offerings claim to be digital marketing platforms that address virtually all digital marketing neighbourhoods, but the methods and objectives of each neighbourhood vary widely (Miles, Stephen Bel., 2003).

The platforms are not the overall solution because it can create lock-in risks as you become dependent on a single-provider specialized platform longer implementation cycle's slow time to value may not are cost-effective to buy a platform for small subset of functionality among these we can talk about Mobile marketing platforms. The factors of Digital marketing are Networks, Security, Information privacy, National ICT policy, and Digital skills. Good financial performance of Commercial banks rewards the shareholders for their investment. This, in turn, encourages additional investment and brings about economic growth. On the other hand, poor banking performance can lead to banking failure and crisis which have negative implications on the economic growth. The determinants of bank performances can be classified into bank specific (internal) and macroeconomic (external) factors (Aburime, 2005; Al-Tamimi, 2010).

\section{RESEARCH METHODOLOGY}

This study adopted descriptive cross sectional survey design. The target population in this study was the employees of BPR, and Equity Bank Rwanda respectively 243 of employees were targeted from BPR and Equity Bank in Kigali City. The purposive sampling technique was used to select 71 of respondents included by 46 employees from BPR and the 25 employees from Equity Bank. The information used in this research was originated from primary and secondary source while data collection techniques were questionnaire and documentary techniques. Data was analysed using both quantitative and qualitative technique and the results were presented by using the descriptive methods of data analysis.

\section{DATA ANALYSIS AND DISCUSSION}

The researcher went to the field to give the questionnaires to the 25 employees from Equity Bank and 46 employees from BPR where all respondents were given three days of responding the questions. However, the participation rate of respondents was $100.0 \%$ for answering the questionnaire.

Table 1: Socio-Demographic Characteristics of Respondents

\begin{tabular}{llcccc}
\hline Data & & \multicolumn{2}{c}{ Equity Bank } & \multicolumn{2}{c}{ BPR Atlas Mara } \\
\cline { 3 - 6 } & & Frequency & Percent & Frequency & Percent \\
\hline Gender & Male & 16 & 64.0 & 26 & 56.5 \\
Balance & Female & 9 & 36.0 & 20 & 43.5 \\
Ages of & Between 21 and 30 years & 8 & 32.0 & 17 & 37.0 \\
\hline
\end{tabular}




\begin{tabular}{llcccc}
\hline Responden & 31 and 40 years & 6 & 24.0 & 18 & 39.1 \\
ts & Between 41 and 50 years & 9 & 36.0 & 9 & 19.6 \\
& 51 years and above & 2 & 8.0 & 2 & 4.3 \\
Level of & Masters' Degree & 3 & 12.0 & 11 & 23.9 \\
education & Bachelor's' Degree & 22 & 88.0 & 35 & 76.1 \\
Marital & Single & 13 & 52.0 & 23 & 50.0 \\
status & Married & 12 & 48.0 & 23 & 50.0 \\
& Less than 1 year & 1 & 4.0 & 9 & 19.6 \\
Experience & 2- 3years & 15 & 60.0 & 9 & 19.6 \\
in Digital & 4- 5years & 9 & 36.0 & 15 & 32.6 \\
marketing & 6years and above & 0 & 0.0 & 16 & 34.8 \\
\hline Total & & $\mathbf{2 5}$ & $\mathbf{1 0 0 . 0}$ & $\mathbf{4 6}$ & $\mathbf{1 0 0 . 0}$ \\
\hline
\end{tabular}

Source: Field data, September 2018

The findings in the table 1 shows socio-demographic characteristics of respondents of BPR Atlas Mara and Equity Bank Rwanda, where males were 64.0\% in BPR, and 56.5\% in Equity Bank. While $36.0 \%$ were females in Equity Bank; and $43.5 \%$ were females in BPR. The range of ages from 21 to 30 years occupied by 35.2\% in Equity Bank, and 37.0\% respondents were in BPR. 31 and 40 years have been by $24.0 \%$ respondents in Equity Bank while in in BPR, they were $39.1 \%$ respondents. 41 and 50 years were 36.0\% in Equity Bank and 19.6\% respondents in BPR. 51 years and above were $8.0 \%$ in Equity Bank while only $4.3 \%$ respondents were from BPR. The $52.0 \%$ of respondents were single in Equity Bank while $50.0 \%$ were in BPR. $48.0 \%$ of respondents were married from Equity Bank and 50.0\% respondents were married from BPR. There is no illiterate employee in both Equity Bank and BPR where $12.0 \%$ respondents from Equity Bank who had Masters' Degree, while 23.9\% of respondents from BPR who have masters. 88.0\% respondents were from Equity Bank who have Bachelor's' Degree while 76.1\% respondents were from BPR who have Bachelor's' Degree. 4.0\% respondents from Equity Bank have experience less than 1 year while $19.6 \%$ of respondents who have less than 1year of experience were from BPR. $60.0 \%$ of respondents from Equity Bank have between 2-3years of working experience while only $19.6 \%$ of respondents in BPR had the experience of 2 to 3years. $36.0 \%$ of respondents of Equity Bank have experiences of 4- 5years while BPR were 32.6\% respondents. There is none who has experience of 6years and above in Equity Bank among the respondents met in this study while in BPR, more than 34.8\% respondents have 6years and above of working experience in this Bank.

\section{VI. a. Common digital marketing platforms used by the commercial banks in Rwanda}

Table 2 illustrates common digital marketing platforms used by BPR and Equity Bank Rwanda. Google Ad was confirmed by $16.0 \%$ in Equity Bank to be digital marketing platform while in BPR was confirmed by $21.7 \%$ of respondents. Facebook was on $40.0 \%$ in Equity Bank while in BPR, it was confirmed by $28.3 \%$ of respondents. Instagram was on rate of $40.0 \%$ in Equity Bank while in BPR, it was on rate of $28.3 \%$. Blogger was $4.0 \%$ in Equity Bank while in BPR; it was confirmed by $8.7 \%$ of respondents. Tweeter was confirmed on zero rate at Equity Bank while in 
BPR, was confirmed on $4.3 \%$ of respondents. E-mail was on zero also in Equity Bank while in BPR; E-mail was confirmed on $8.7 \%$ of respondents.

Table 2. Common Digital marketing Platforms used by BPR and Equity Bank Rwanda

\begin{tabular}{lcccc}
\hline \multirow{2}{*}{\begin{tabular}{c} 
Digital marketing \\
\multicolumn{1}{c}{ Platforms }
\end{tabular}} & \multicolumn{2}{c}{ Equity Bank } & \multicolumn{2}{c}{ BPR Atlas Mara } \\
\cline { 2 - 5 } & Frequency & Percent & Frequency & Percent \\
\hline Google Ad & 4 & 16.0 & 10 & 21.7 \\
Facebook & 10 & 40.0 & 13 & 28.3 \\
Instagram & 10 & 40.0 & 13 & 28.3 \\
Blogger & 1 & 4.0 & 4 & 8.7 \\
Tweeter & 0 & 0.0 & 2 & 4.3 \\
E-mail & 0 & 0 & 4 & 8.7 \\
Total & $\mathbf{2 5}$ & $\mathbf{1 0 0 . 0}$ & $\mathbf{4 6}$ & $\mathbf{1 0 0 . 0}$ \\
\hline
\end{tabular}

Source: Field data, 2018

VI. b. The application of digital marketing has improved customers convenience in the BPR and Equity Bank in Rwanda

Table 3 illustrates the services of digital marketing platforms inquire in BPR and Equity Bank Rwanda. Mobile banking was confirmed by 15.2\% in BPR; Account opening was on 13.0\% IN BPR; account management was on rate of $28.0 \%$ in Equity Bank and 32.6\% in BPR; Card Payments was on $28.0 \%$ in Equity Bank and 15.2\% in BPR, Money transfers was confirmed by $40.0 \%$ of respondents in Equity Bank in Rwanda while 21.7\% were from BPR. Saving/withdraw was confirmed on rate of $4.0 \%$ and $2.2 \%$ in BPR.

Table 3. The services of Digital marketing Platforms inquire in the Bank

\begin{tabular}{lcccc}
\hline \multirow{2}{*}{$\begin{array}{c}\text { Services of Digital marketing } \\
\text { Platforms }\end{array}$} & \multicolumn{2}{c}{ Equity Bank } & \multicolumn{2}{c}{ BPR Atlas Mara } \\
\cline { 2 - 5 } & Frequency & Percent & Frequency & Percent \\
\hline Mobile banking & 0 & 0.0 & 7 & 15.2 \\
Account opening & 0 & 0.0 & 6 & 13.0 \\
Account management & 7 & 28.0 & 15 & 32.6 \\
Card Payments & 7 & 28.0 & 7 & 15.2 \\
Money transfers & 10 & 40.0 & 10 & 21.7 \\
Saving/withdraw & 1 & 4.0 & 1 & 2.2 \\
Total & 25 & 100.0 & 46 & 100.0 \\
\hline
\end{tabular}

Source: Field data, September 2018

VI. C. The application of Digital marketing Platforms help in reducing marketing cost against traditional marketing in commercial banks in Rwanda

Table 4 shows the $28.0 \%$ of respondents in Equity Bank said that digital marketing reduces the cost very high. 50.0\% respondents in BPR said that digital marketing reduce the cost of marketing for Bank in very high. 52.0\% respondents in Equity Bank confirmed that digital marketing reduce the cost of marketing for Bank as channel of performance in high and 39.1\% 
Proc. of the Seventh Intl. Conf. on Advances in Social Science, Economics and Management Study - SEM 2018 Copyright (C) Institute of Research Engineers and Doctors, USA .All rights reserved.

ISBN: 978-1-63248-164-1 DOI : 10.15224/978-1-63248-164-1-29

respondents in BPR said it is high. 20.0\% respondents in Equity Bank said that digital marketing reduce the cost of marketing for Bank as channel of performance was moderate and $10.9 \%$ respondents confirmed that digital marketing reduce the cost of marketing for Bank as channel of performance was moderate.

Table 4. The level of how digital marketing reduce the cost of marketing for Bank as channel of performance

\begin{tabular}{ccccc}
\hline Digital marketing reduce & \multicolumn{2}{c}{ Equity Bank } & \multicolumn{2}{c}{ BPR Atlas Mara } \\
\cline { 2 - 5 } the cost of marketing & Frequency & Percent & Frequency & Percent \\
\hline Very High & 7 & 28.0 & 23 & 50.0 \\
High & 13 & 52.0 & 18 & 39.1 \\
Moderate & 5 & 20.0 & 5 & 10.9 \\
Total & 25 & 100.0 & 46 & 100.0 \\
\hline
\end{tabular}

Source: Field data, 2018

Table 5 presents the perceptions on marketing system as more convenient for staff of Bank. 92.0\% of respondents in Equity Bank confirmed digital marketing of marketing system is more convenient for staff of Bank while $73.9 \%$ respondents in BPR, they confirmed that digital marketing is more convenient for this Bank. An integration of the both digital and traditional marketing is more convenient for staff of Bank; this is confirmed by $8.0 \%$ respondents in Equity Bank and 26.1\% respondents in BPR.

Table 5. Marketing System which is more convenient for staff of Bank

\begin{tabular}{llcccc}
\hline Marketing System which is more & \multicolumn{2}{c}{ Equity Bank } & \multicolumn{2}{c}{ BPR Atlas Mara } \\
\cline { 3 - 6 } \begin{tabular}{l} 
convenient \\
\cline { 3 - 6 }
\end{tabular} & Frequency & Percent & Frequency & Percent \\
\hline $\begin{array}{l}\text { Digital marketing } \\
\text { An integration of the both digital }\end{array}$ & 23 & 92.0 & 34 & 73.9 \\
$\begin{array}{l}\text { Total } \\
\text { Totional marketing }\end{array}$ & 2 & 8.0 & 12 & 26.1 \\
\hline
\end{tabular}

Source: Field data, 2018

Table 6 shows where on the scale would respondents rate digital marketing regarding reducing cost of operation for their banks. 56.0\% respondents in Equity Bank confirmed that the rate of digital marketing in reducing cost of operation was Excellent and $47.8 \%$ respondents in BPR. 32.0\% respondents in Equity Bank confirmed the rate was very Good, and 34.8\% respondents in BPR. While $12.0 \%$ of respondents in Equity Bank said that they rate of digital marketing in reducing cost of operation for the bank as Good, and 17.4\% respondents in BPR.

Table 6. Rate of digital marketing in reducing cost of operation for the bank

\begin{tabular}{ccccc}
\hline Rate of digital marketing & \multicolumn{2}{c}{ Equity Bank } & \multicolumn{2}{c}{ BPR Atlas Mara } \\
\cline { 2 - 5 } in reducing cost & Frequency & Percent & Frequency & Percent \\
\hline Excellent & 14 & 56.0 & 22 & 47.8 \\
Very Good & 8 & 32.0 & 16 & 34.8 \\
Good & 3 & 12.0 & 8 & 17.4 \\
Total & 25 & 100.0 & 46 & 100.0 \\
\hline
\end{tabular}


Source: Field data,2018

Table of model summary shows analysis of digital marketing Platforms included by mail marketing, Tweeter, Face book, Blogger, Google Ad, Instagram on performance of bank where R-Square was .184 while Adjusted R-Square was .107. The study used a linear regression to analyse Digital marketing Platforms in terms of "Google Ad; Facebook; instagram; Blogger; Tweeter; and E-mail marketing" as independent variables, and with performance of Equity Bank and BPR in terms of " increased profitability; large market share; quality products/service package; reduction of bank queues; and customer loyalty" as dependent variables. $Y=\beta_{0}+\beta_{1} X_{1}+\beta_{2} X_{2}+\beta_{3} X_{3}+\beta_{4} X_{4}+\beta_{5} X_{5}+\beta_{6} X_{6}+\varepsilon$

Where, $\mathbf{Y}$ is dependent variable indicator which is "performance" $\mathbf{X}$ is independent variable factor which are "Digital Marketing platforms".

The results show $Y=4.098+.204 X_{1}+.347 X_{2}+.013 X_{3}+.148 X_{4}+.179 X_{5}+1.196 X_{6}+\varepsilon$.

Hence, $X_{1}$ represent Google Ad, $X_{2}$ represent Face book, $X_{3}$ is Instagram, $X_{4}$ is Blogger; $X_{5}$ presents Tweeter while $\mathrm{X}_{6}$ shows E-mail marketing and $\varepsilon$ represents standard errors. As explained by the linear regression equation, it is clear that one unit change of $X_{1}, X_{2}, X_{3}, X_{4}, X_{5}$, and $\mathrm{X}_{6}$ lead to change times $0.204 ; 0.347 ; 0.013 ; 0.148 ; 0.179$; and 1.196 of dependent variable respectively. In the other case if all independent variable indicators are zero, the dependent variable equals to the constant (4.098).

Table 7. Statistics Coefficients ${ }^{\mathrm{a}}$

\begin{tabular}{|c|c|c|c|c|c|c|}
\hline \multirow{2}{*}{\multicolumn{2}{|c|}{ Model }} & \multicolumn{2}{|c|}{$\begin{array}{l}\text { Unstandardized } \\
\text { Coefficients }\end{array}$} & \multirow{2}{*}{$\begin{array}{l}\text { Standardized } \\
\text { Coefficients } \\
\text { Beta }\end{array}$} & \multirow[t]{2}{*}{$\mathrm{T}$} & \multirow[t]{2}{*}{ Sig. } \\
\hline & & B & Std. Error & & & \\
\hline \multirow{7}{*}{1} & (Constant) & 4.098 & 1.559 & & 2.629 & .011 \\
\hline & Google Ad & .204 & .296 & .091 & 691 & .092 \\
\hline & Face book & .347 & .293 & 162 & 1.185 & .040 \\
\hline & Instagram & .013 & .319 & .006 & .042 & .067 \\
\hline & Blogger & .148 & .229 & 081 & .645 & .021 \\
\hline & Tweeter & .179 & .217 & . 104 & .827 & .012 \\
\hline & E-mail marketing & 1.196 & .497 & .336 & 2.407 & .019 \\
\hline
\end{tabular}

a. Dependent Variable: performance

Table 8. Financial performance analysis ratios of BPR

\begin{tabular}{lcccc}
\hline Years & ROA & ROE & GPM & NPM \\
\hline 2013 & $(3,28 \%)$ & $(37,48 \%)$ & $96.9 \%$ & $(25.1 \%)$ \\
2014 & $576,22 \%$ & $5722,64 \%$ & $98.1 \%$ & $4562,2 \%$ \\
2015 & $(1,15 \%)$ & $(14,24 \%)$ & $97.5 \%$ & $(9.4 \%)$ \\
2016 & $184,50 \%$ & $1117,73 \%$ & $97.8 \%$ & $1569,9 \%$ \\
2017 & $50,42 \%$ & $323,07 \%$ & $103.9 \%$ & $592,5 \%$ \\
\hline
\end{tabular}

Source: Secondary data, 2017 
Proc. of the Seventh Intl. Conf. on Advances in Social Science, Economics and Management Study - SEM 2018 Copyright (C) Institute of Research Engineers and Doctors, USA .All rights reserved.

ISBN: 978-1-63248-164-1 DOI : 10.15224/978-1-63248-164-1-29

Table 9. Financial performance analysis of Equity Bank

\begin{tabular}{lcccc}
\hline Years & ROA & ROE & GPM & NPM \\
\hline $\mathbf{2 0 1 3}$ & $0,55 \%$ & $2,34 \%$ & $99,83 \%$ & $2,37 \%$ \\
$\mathbf{2 0 1 4}$ & $0,70 \%$ & $3,21 \%$ & $87,12 \%$ & $2,93 \%$ \\
$\mathbf{2 0 1 5}$ & $0,74 \%$ & $3,52 \%$ & $94,33 \%$ & $3,23 \%$ \\
$\mathbf{2 0 1 6}$ & $3,67 \%$ & $17,93 \%$ & $112,26 \%$ & $15,93 \%$ \\
$\mathbf{2 0 1 7}$ & $1,52 \%$ & $6,90 \%$ & $114,56 \%$ & $6,85 \%$ \\
\hline
\end{tabular}

Source: Secondary data, EQUITY BANK annually reports, 2017

\section{RESEARCH FINDINGS}

From the responses it can also be outlined that there is an increase of performance while using digital marketing platforms in commercial banks in Rwanda. This is justified by males, and females found in these commercial banks. The digital marketing platforms used by BPR and Equity Bank were confirmed to be Google Ad; Blogger; E-mail and Tweeters which applied for Mobile banking; Account opening; Account management; Card Payments; and Money transfers in BPR and Equity Bank. Then, to use the platforms of digital marketing increased the level of performance of both banks as confirmed by selected respondents. The justification was given by net profit ratio of BPR in 2013 which was (25.1\%); in 2014, net profit was 4562,2\%; in 2015,NP was -9.4\%; in 2016, NP was 1569,9\% and in 2017, NP was 592,5\% at BPR while for Equity Bank, NP was 2,37\% in 2013; in 2014, net profit was 2,93\%; in 2015,NP was 3,23\%; in 2016, NP was 15,93\% and in 2017, NP was 6,85\% at Equity Bank. Therefore, according to data collect from respondents of both Banks, digital marketing reduces the cost on Very High level in BPR and Equity Bank

\section{CONCLUSION}

The study further concludes that the internet is the main digital platform adopted most commercial banks as the digital advertising platform as it provides a communication platform on which digital content can be delivered to a wide population. However the findings help us to say that the problem of the study was solved, research objectives were achieved, and research questions were answered where we confirm that there is significant effect of digital marketing and performance of commercial banks in Rwanda.

\section{RECOMMENDATIONS}

Due to the high growth rate of social communities most businesses ought to realize the potential of social media marketing in reaching the larger audience. The study recommends that the sooner the marketers dive in and begin experimenting in the Digital marketing Platforms, the more successful they will be in the future. The use of digital communication platforms are important to commercial banks so as increase their visibility and increase their customer base. 


\section{REFERENCES}

Abu Bakar, A., R., \& Ahmed, Z., U., (2015) Technology motivation in e-marketing adoption among Malaysian manufacturers. Journal of Transnational Management, 20(2), 126152.

Aburime, and Al-Tamimi, (2010) The determinants of bank performances as classified into bank specific (internal) and macroeconomic (external) factors

Armstrong and Kotler (2014) Marketing channels as persons, organizations or even other activities necessary for transferring ownership of goods

Gagliardone, I., \& Golooba-Mutebi, F. (2016). The Evolution of the Internet in Ethiopia and Rwanda.

Kaye \& Medoff, (2001). Marketing orientation and its determinants: an empirical analysis. European journal of marketing, 33(11/12), 1003-1037

Malunda, D., \& Musana, S., (2012) Rwanda case study on economic transformation: report for the African Centre for Economic Transformation (ACET)

National Bank of Rwanda (NBR Report, 2014), gap between the information received by customers regarding payment of cheques between banks

Sheikh, A. A., Shahzad, A., \& Ishak, A. K. (2016). The Evolution of E-Marketing In BusinessTo-Business (B2b) Environment And Its Impact On Firm Performance. Journal studia universitatis babes-bolyai negotia.

Sheikh, A. A., Shahzad, A., \& Ishaq, A. K. (2017). The Growth of E-Marketing in Business-toBusiness Industry and its Effect on the Performance of Businesses in Pakistan: Marketing Success. International and Multidisciplinary Journal of Social Sciences, 6(2), 178-214.

Strauss and Frost (2001) digital marketing as the use of electronic data and applications for planning and executing 